\title{
PENINGKATKAN MOTIVASI BELAJAR SISWA DALAM PEMBELAJARAN MICROSOFT EXCEL DENGAN MENGGUNAKAN METODE TUTOR SEBAYA DI KELAS VIII-D SMP NEGERI 1 BATANGKUIS
}

\author{
Hari Indrawan Siregar \\ Guru SMP Negeri 1 Batangkuis, Kabupaten Deli Serdang \\ Surel : indrawanabdullah@gmail.com
}

\begin{abstract}
Abstrak
Penelitian ini bertujuan untuk meningkatkan motivasi belajar siswa dalam pelajaran TIK dengan menggunakan metode tutor sebaya. Proses penelitian ini dilaksanakan dalam dua siklus masing-masing 4 kali pertemuan. Hasil penelitian menunjukkan peningkatan motivasi belajar siswa, pada observasi awal siswa yang bermotivasi tinggi hanya sebanyak $13.95 \%$ dengan rerata capaian $42.83 \%$ dari indikator motivasi belajar, meningkatan menjadi $22.73 \%$ dengan rerata capaian $44.21 \%$ pada pertengahan siklus 1 dan menjadi $50.00 \%$ dengan rerata capaian $68.04 \%$ pada akhir siklus 1 . Pada pertengahan siklus 2 siswa yang bermotivasi tinggi naik mencapai 77. 27\% dengan rerata capaian $73.65 \%$, dan di akhir siklus 2 mencapai $88.64 \%$ dengan rerata capaian $76.56 \%$ dari indikator motivasi belajar siswa.
\end{abstract}

Kata Kunci : Motivasi, Tutor Sebaya, Metode Pembelajaran

\section{PENDAHULUAN}

Pendidikan merupakan upaya mencetak sumber daya manusia (SDM) yang berkualitas, beriman, bertaqwa kepada Tuhan Yang Maha Esa, berbudi pekerti luhur dan berkemampuan tinggi akan dapat dicapai. Undang - Undang Sistem Pendidikan Nasional No. 20 Tahun 2003 mengamanatkan bahwa pendidikan adalah usaha sadar dan terencana untuk mewujudkan suasana belajar dan proses pembelajaran agar peserta didik secara aktif mengembangkan potensi dirinya untuk memiliki kekuatan spiritual keagamaan, pengendalian diri, kepribadian, kecerdasan, akhlak mulia, serta keterampilan yang diperlukan dirinya, masyarakat, bangsa dan negara.

Permendiknas No 22 Tahun 2006 menyebutkan bahwa mata pelajaran Teknologi Informasi dan Komunikasi (TIK) perlu diperkenalkan, dipraktikkan dan dikuasai peserta didik sedini mungkin agar mereka memiliki bekal untuk menyesuaikan diri dalam kehidupan global yang ditandai dengan perubahan yang sangat cepat. Untuk menghadapi perubahan tersebut diperlukan kemampuan dan kemauan belajar sepanjang hayat dengan cepat dan cerdas. Hasil-hasil teknologi informasi dan komunikasi banyak membantu manusia, diantaranya dimanfaatkan untuk 
merevitalisasi proses belajar yang pada akhirnya dapat mengadaptasikan peserta didik dengan lingkungan dan dunia kerja.

Microsoft Excel merupakan salah satu perangkat lunak pengolah angka yang umumnya jadi materi pokok dalam pelajaran Teknologi Informasi dan Komunikasi (TIK) untuk kelas VIII SMP. Saat ini perangkat lunak pengolah angka sudah banyak tersedia baik dari yang didapat dengan bayar dan juga gratis. Ada beberapa macam software atau perangkat lunak pengolah angka di antaranya adalah Microsoft Office Excel (versi 97, 2000, 2003, 2007, dst), Lotus 1-2-3, Borland Quattro, Visicalc, Boeing Calc 3D, Lotus Improv, Javelin Software, Lotus Jazz for Mac, Lucid 3D, Gnumeric dan OpenOffice.org Calc. Semua itu mempunyai fungsi yang sama yaitu mengolah angka. Fasilitas-fasilitas yang disediakan dalam perangkat lunak pengolah angka ini memungkinkan siswa dapat dengan cepat dan mudah bekerja untuk mengevaluasi, merevisi data perhitungan dan perbandingan harga serta untuk membuat laporan dalam bentuk tabel dan diagram grafik (Endang, 2009: 122).

$$
\text { Pada setiap pembelajaran }
$$
terkait materi ini seharusnya dilaksanakan di ruang komputer. Keterbatasan fasilitas sekolah yang ada menyebabkan siswa harus masuk ke laboratorium secara bergantian dengan cara membagi dua kelompok siswa, hal ini dilakukan karena sarana komputer yang tidak cukup untuk seluruh siswa yang berjumlah 34 - 44 siswa sementara komputer yang ada berkisar kurang dari 10 unit dan itupun kondisinya belum tentu dalam keadaan baik. Pembelajaran komputer juga kerap diberikan secara klasikal, sehingga kegiatan pembelajaran cenderung berfokus pada teoritis dari pada praktik. Lambat laun hal ini menyebabkan para siswa kehilangan semangat dan motivasi belajar.

Kondisi pembelajaran seperti dijelaskan sebelumnya menimbulkan beberapa permasalahan, antara lain: pertama, siswa belajar hanya satu jam pelajaran untuk setiap kelompok sehingga pengerjaan latihan dibutuhkan beberapa kali pertemuan dan terbatasnya kesempatan untuk siswa mengembangkan kreatifitasnya; kedua, hasil belajar pada setiap pengerjaan latihan tidak tercapai tepat waktu, ketiga, penyampaian materi dengan menggunakan LCD proyektor meskipun cukup membantu guru dalam menjelaskan materi namun belum mebatu secara maksimal karena sifat penyampaian yang berbentuk gambar-gambar perintah yang terbatas sehingga penyampian materi kurang jelas; keempat, siswa selalu lupa materi pelajaran (teori, perintah, gambar dan cara-cara melakukan prosedur pengerjaan); kelima, karena siswa dibagi dalam dua kelompok maka menerangkan materi pelajaran menjadi dua kali juga dan itu secara psikologis memberikan pengaruh kepada pengajar; keenam, keadaan seperti ini 
menyebabkan motivasi belajar siswa menjadi menurun yang pada akhirnya menyebabkan hasil pembelajaran pun menjadi kurang memuaskan.

Rendahnya hasil belajar peserta didik ini terlihat dari hasil observasi guru di kelas VIII-D yang dilaksanakan pada 23 Januari 2015 bahwa hasil belajar TIK pada peserta didik SMP Negeri 1 Batang Kuis dengan Nilai KKM (Kriteria Ketuntasan Minimal) 70, dari 43 peserta didik yang mengikuti Evaluasi KD 2.1 terdapat ketuntasan belajar hanya pada 6 peserta didik (13.95\%), dan yang tidak tuntas sebanyak 37 peserta didik $(86.05 \%)$ dengan nilai tertinggi 80 , dan nilai terendah 28 sedangkan rata-rata hasil belajar peserta didik 50.79 dengan kehadiran peserta didik sebesar 43 peserta didik (95.56\%). Permasalahan rendahnya nilai hasil belajar perserta didik ini diakibatkan pembalajaran TIK lebih dominan kepada guru dengan model ceramah, dan minimnya sarana prasana.

Penelitian ini berupaya mengatasi lemahnya motivasi belajar siswa dengan meningkatkan inovasi dan kreativitas guru agar kegiatan pembelajaran yang berlangsung monoton dan membosankan dapat diatasi. Salah satu pendekatan pembelajaran yang diduga mampu mewujudkan situasi pembelajaran yang kondusif, aktif, kreatif, efektif, dan menyenangkan adalah pendekatan dengan metode tutor sebaya.
Pembelajaran dengan metode tutor sebaya ini, guru memberdayakan siswa-siswa yang memiliki kemampuan di atas ratarata siswa lainnya untuk diperbantukan dalam menyampaikan materi kepada teman-temannya yang belum memahami materi, sehingga target ketuntasan belajar terpenuhi. Beberapa ahli percaya bahwa satu mata pelajaran benar-benar dikuasai hanya apabila seseorang peserta didik mampu mengajarkan kepada peserta didik lainnya (Silberman, 1996: 165). Pembelajaran tutor sebaya ini akan meningkatkan fungsi guru sebagai fasilitator dan pendamping dalam proses belajar mengajar, dengan kreatifitasnya sang guru dapat memberikan pengalaman mengajar bagi para siswa tutor untuk meneruskan pemahamannya kepada teman sekelasnya.

Berdasarkan permasalah yang dipaparkan di atas, rumusan masalah dalam Penelitian Tindakan Kelas (PTK) ini adalah: sejauh manakah penggunaan metode tutor sebaya dapat meningkatkan motivasi belajar siswa dalam pembelajaran Microsoft Excel? Bagaimanakah penerapan metode tutor sebaya pada pembelajaran Microsoft Excel? Apakah penggunaan tutor sebaya dapat meningkatkan ketuntasan siswa dalam belajar Microsoft Excel?

Tujuan yang diharapkan setelah penelitian ini adalah terjadinya peningkatan motivasi belajar siswa dalam belajar Microsoft Excel, guru mampu mengidentifikasi langkah-langkah yang perlu 
dilakukan dan mengembangkan pembelajaran dengan metode tutor sebaya, dan terjadinya peningkatan ketuntasan belajar siswa pada pembelajaran Microsoft Excel.

\section{METODOLOGI PENELITIAN}

Penelitian dilaksanakan di SMP Negeri 1 Batangkuis Kecamatan Batangkuis Kabupaten Deli Serdang. Penelitian ini dilaksanakan selama 3 (tiga) bulan, dimulai sejak bulan Februari sampai dengan Mei 2015 semester Genap Tahun Pelajaran 2014/2015. Subjek Penelitian ini adalah siswa kelas VIII-D yang berjumlah 45 orang, 21 siswa laki-laki dan 24 Siswa Perempuan.

Defenisi operasional dari motivasi belajar siswa adalah dorongan dan kebutuhan dalam belajar, yang memiliki ciri; tekun mengerjakan tugas, tahan menghadapi kesulitan, senang belajar mandiri, percaya pada kemampuan, senang mencari dan memecahkan soal-soal, sehingga belajar menjadi hal yang menarik dan terjadi perlombaan di lingkungan belajar, untuk mencapai keberhasilan siswa dalam pembelajaran Microsoft Excel di kelas VIII. Indikator dari motivasi belajar yang digunakan antara lain :
a. Adanya dorongan dan kebutuhan dalam belajar,
b. Tekun mengerjakan tugas,
c. Tahan menghadapi kesulitan,
d. Senang bekerja mandiri dan percaya pada kemampuan sendiri,

e. Senang mencari dan memecahkan soal-soal,

f. Adanya hasrat dan keinginan berhasil,

g. Adanya kegiatan yang menarik dalam belajar,

h. Terjadi perlombaan di lingkungan belajar.

Desain penelitian yang digunakan adalah penelitian tindakan kelas (Classroom Action Research), yaitu sebuah penelitian yang dilakukan oleh guru di kelasnya sendiri dengan jalan merancang, melaksanakan, dan merefleksikan tindakan secara kolaboratif dan partisipatif dengan tujuan untuk memperbaiki kinerjanya sebagai guru sehingga hasil belajar siswa dapat meningkat (Rustam dan Mundilarto, 2004: 1).

Penelitian direncanakan akan berlangsung selama dua siklus, yang masing-masing terdiri dari: perencanaan (plan), pelaksanaan (act), pengamatan (observe), dan refleksi (reflect). Tiap siklus minimal akan terdiri dari 3 sampai dengan 4 pertemuan tatap muka sehingga keseluruhan penelitian akan terdiri dari sekitar dua belas pertemuan tatap muka. Siklus "plan - act observe - reflect" akan berlangsung terus sampai kriteria keberhasilan mencapai minimal $60 \%$ dari indikator motivasi belajar yang terdapat pada $75 \%$ siswa.

Instrumen penelitian yang digunakan untuk pengumpulan data dalam penelitian tindakan kelas ini berupa instrumen nontes (berupa lembar observasi dan catatan harian), 
dan instrument tes. Tes instrumen pengumpulan data untuk mengukur kemampuan peserta didik dalam aspek kognitif, atau tingkat penguasaan materi pelajaran. Bentuk instrumen yang digunakan berupa tes Unjuk Kerja secara individual.

Data hasil belajar siswa akan dianalisis dengan statistik deskriptif, seperti rata-rata dan persentase. Peningkatan motivasi belajar akan dilihat dari kecenderungan kenaikan motivasi yang diperoleh dari format observasi dan catatan lapangan (field notes). Data dari lembar observasi dan pedoman wawancara akan dianalisis secara kualitatif, kemudian dilihat juga kecenderungannya dari siklus ke siklus.

Kolaborator penelitian adalah teman sejawat yang masuk pada kelas yang sama meski mengampu mata pelajaran yang berbeda. Pada saat-saat tertentu, kolaborator ikut masuk kelas untuk membantu melakukan observasi dan membantu mengamati pelaksanaan pembelajaran dengan model pembelajaran tutor sebaya. Kolaborasi juga dilakukan untuk menerima saran tentang perencanakan tindakan untuk minggu berikutnya.

\section{HASIL PENELITIAN DAN PEMBAHASAN}

Perencanaan siklus didasarkan pada temuan observasi awal yang terdapat pada table 4.1 dan table 4.2. Pada table 4.1 disimpulkan, peserta didik yang mengikuti Evaluasi KD
2.1 ternyata hanya $13.95 \%$ yang tuntas belajar, $86.05 \%$ tidak tuntas, nilai tertinggi 80 , nilai terendah 28 , dan nilai rata-rata hasil belajar 50.79 dengan nilai KKM (Kriteria Ketuntasan Minimal) adalah 70, jumlah peserta didik yang hadir 43 orang (95.56\%). Pada table 4.2 disimpulkan, dari 43 peserta didik yang diberikan pengujian motivasi belajar hanya $4.65 \%$ yang memiliki Motivasi Baik Sekali, $9.30 \%$ memiliki Motivasi Baik, 23.26\% memiliki Motivasi Sedang, dan $62.79 \%$ memiliki Motivasi belajar Kurang, dengan rerata capaian $42.83 \%$ dari indikator motivasi belajar siswa.

\section{Data Siklus I}

\section{Perencanaan}

Penelitian dalam siklus I ini dilakukan sebanyak 4 kali pertemuan atau 8 kali 40 menit. Bentuk perencanaan pada penelitian ini yang dilakukan pada siklus I adalah:

a. Membuat Rencana Pelaksanaan Pembelajaran (RPP).

b. Membuat format evaluasi (penilaian) belajar untuk mengetahui sejauhmana capaian keberhasilan.

c. Mempersiapkan soal dan lembar hasil belajar peserta didik.

d. Menyusun format format penilaian (unjuk kerja) dan observasi.

e. Mempersiapkan format observasi motivasi belajar peserta didik dan catatan lapangan (field note) yang akan 
diamati oleh peneliti dan/atau observer.

\section{Pelaksanaan Tindakan Siklus 1}

Kelompok yang menjadi tutor masuk ruang komputer untuk mendapat materi secara langsung dari guru pengajar selama 20 menit. Guru menjelaskan secara cepat materi kepada para tutor. Setelah 20 menit Guru melakukan tanya jawab dan menjelaskan kesimpulan dari kegiatan belajar. Selanjutnya masing-masing gelombang siswa akan masuk ruang komputer selama 30 menit sesuai kelompoknya masing-masing dengan dibimbing oleh kelompok tutor.

Pada akhir siklus 1 (pertemuan ke-3), kelompok yang menjadi tutor masuk ruang komputer untuk mendapat materi secara langsung dari guru pengajar selama \pm 30 menit diluar jam pelajaran sehari sebelumnya. Selanjutnya masing-masing gelombang siswa akan masuk ruang komputer selama 40 menit sesuai kelompoknya masing-masing dengan dibimbing oleh kelompok tutor.

\section{Pengamatan}

$\begin{array}{rrr} & \text { Pada siklus I ini dilaksanakan } \\ 2 & \text { kali observasi } & \text { terhadap } \\ \text { instrument } & \text { motivasi } & \text { belajar, }\end{array}$ pertama dilakukan bersamaan dengan evaluasi KD 2.2 pada pertengahan siklus I dan evaluasi KD 2.3 pada saat akhir siklus I. Data yang diperoleh dari kedua evaluasi ini menunjukkan telah terjadi peningkatan ketuntasan belajar siswa dari sebelum menggunakan metode tutor sebaya. Peningkatan hasil belajar dan motivasi ditunjukkan dalam tabel 4.5 dan tabel 4.8 berikut:

Tabel 4.5.

Perbandingan Hasil Evaluasi Belajar Sebelum dan Setelah Menggunakan Metode Tutor Sebaya (Pada Siklus 1)

\begin{tabular}{|c|c|c|c|c|c|c|}
\hline \multirow{2}{*}{$\begin{array}{c}\text { Perbandingan Hasil } \\
\text { Belajar }\end{array}$} & \multirow{2}{*}{ Observasi Awal } & \multicolumn{4}{|c|}{ Observasi Pada Siklus 1 } \\
\cline { 4 - 7 } & & \multicolumn{2}{|c|}{ Observasi 1 } & \multicolumn{2}{c|}{ Observasi 2 } \\
\hline Nilai Tertinggi & 80 & & 100 & & 100 & \\
\hline Nilai Terendah & 28 & & 37.5 & & 50 & \\
\hline Rata-Rata Nilai & 50.79 & & 62.50 & & 68.98 & \\
\hline Ketuntasan & 6 & $13.95 \%$ & 11 & $25.00 \%$ & 26 & $59.09 \%$ \\
\hline Tidak Tuntas & 37 & $86.05 \%$ & 33 & $75.00 \%$ & 18 & $40.91 \%$ \\
\hline KEHADIRAN & & & & & & \\
\hline Hadir & 43 & $95.56 \%$ & 44 & $97.78 \%$ & 44 & $97.78 \%$ \\
\hline Tidak Hadir & 2 & $4.44 \%$ & 1 & $2.22 \%$ & 1 & $2.22 \%$ \\
\hline Jumlah Keseluruhan & 45 & $100.00 \%$ & 45 & $100.00 \%$ & 45 & $100.00 \%$ \\
\hline
\end{tabular}


Tabel 4.8.

Perbandingan Kualitas Motivasi Belajar Sebelum Dan Sesudah Menggunakan Metode Tutor Sebaya

\begin{tabular}{|c|c|c|c|c|c|c|c|c|c|}
\hline \multirow{3}{*}{\begin{tabular}{|c|} 
Perbandingan \\
Kualitas Motivasi \\
Belajar \\
\end{tabular}} & \multirow{2}{*}{\multicolumn{3}{|c|}{ Observasi Awal }} & \multicolumn{6}{|c|}{ Observasi Pada Siklus 1} \\
\hline & & & & \multicolumn{3}{|c|}{ Observasi 1} & \multicolumn{3}{|c|}{ Observasi 2} \\
\hline & $\mathrm{Jlh}$ & $\%$ & & $\mathrm{Jlh}$ & $\%$ & & $\mathrm{Jlh}$ & $\%$ & \\
\hline Baik Sekali & 2 & $4.65 \%$ & \multirow{2}{*}{$13.95 \%$} & 4 & $9.09 \%$ & \multirow{2}{*}{$22.73 \%$} & 6 & $13.64 \%$ & \multirow{2}{*}{50.0} \\
\hline Baik & 4 & $9.30 \%$ & & 6 & $13.64 \%$ & & 16 & $36.36 \%$ & \\
\hline Sedang & 10 & $23.26 \%$ & \multirow{2}{*}{$86.05 \%$} & 13 & $29.55 \%$ & \multirow{2}{*}{$77.27 \%$} & 12 & $27.27 \%$ & \multirow{2}{*}{$50.00 \%$} \\
\hline Kurang & 27 & $62.79 \%$ & & 21 & $47.73 \%$ & & 10 & $22.73 \%$ & \\
\hline Jumlah & 43 & $100.00 \%$ & $100.00 \%$ & 44 & $100.00 \%$ & $100.00 \%$ & 44 & $100.00 \%$ & 100.00 \\
\hline Rerata Capaian & 18.42 & $42.83 \%$ & & 19.455 & $44.21 \%$ & & 21.77 & $68.04 \%$ & \\
\hline
\end{tabular}

Refleksi

Berdasarkan dari temuan diatas maka dapat dikatakan bahwa telah terjadi peningkatan motivasi belajar siswa kearah yang makin baik setelah dilakukan perubahan metode belajar menggunakan tutor sebaya. Hal ini terlihat dari terus berkurangnya siswa yang memiliki motivasi belajar rendah (Sedang dan Kurang) antara sebelum dan sesudah menggunakan metode tutor sebaya. Pada observasi awal ditemukan siswa yang bermotivasi tinggi (Baik dan Baik Sekali) hanya sebanyak $13.95 \%$, dengan rerata capaian $42.83 \%$ dari indikator motivasi belajar siswa pada awal observasi, selanjutnya mengalami kenaikan menjadi $22.73 \%$ dengan rerata capaian $44.21 \%$ dari indikator motivasi belajar siswa pada pertengahan siklus 1 dan menjadi $50.00 \%$ dengan rerata capaian $68.04 \%$ dari indikator motivasi belajar siswa pada akhir siklus 1 .
Peningkatan ketuntasan belajar juga mengalami kenaikan antara sebelum dan sesudah menggunakan metode tutor sebaya. Pada observasi awal ketuntasan belajar hanya pada 6 orang siswa (13.95\%), setelah menggunakan metode tutor sebaya mengalami kenaikan pada pertengahan siklus 1 yaitu menjadi 11 orang siswa (25.58\%), dan menjadi 26 orang siswa $(60.47 \%)$ pada akhir siklus 1 .

Peningkatan ini tidak lepas perubahan tindakan yang dilakukan yaitu terhadap tutor dan siswa. Pada awal siklus 1 peneliti membagi waktu ( 2 x 40 menit $=80$ menit $)$, yaitu: 20 menit untuk membina tutor, dan 60 menit ( 2 x 30 menit) untuk waktu yang disediakan terhadap tutor melakukan pembelajaran pada 2 gelombang. Pada akhir siklus 1, pembinaan terhadap tutor dilakukan secara terpisah, yaitu 30 menit diluar jam pelajaran sekolah dan dalam kegiatannya dikelas para tutor dibekali dengan catatan materi 
panduan pembelajaran yang akan membantu dalam kegiatan tutor sebaya. Pemberian pembinaan secara terpisah menyebabkan waktu kegiatan tutor sebaya jadi semakin panjang dari 60 menit $(2 \times 30$ menit) untuk 2 gelombang menjadi 80 menit ( $2 \times 40$ menit) untuk 2 gelombang.

Berdasarkan data dan uraian diatas maka disimpulkan masih diperlukan usaha perencanaan dan pengembangan yang lebih matang dalam menemukan bentuk metode tutor sebaya yang paling ideal dalam meningkatkan motivasi belajar siswa. Untuk itulah penggunaan tutor sebaya ini akan dilanjutkan pada siklus 2, agar kriteria keberhasilan mencapai minimal $60 \%$ dari indikator motivasi belajar yang terdapat pada $75 \%$ siswa.

\section{Data Siklus II}

Perencanaan

Pelaksanaannya penelitian dalam siklus II ini peneliti dibantu seorang observer yang merupakan rekan kerja sesama guru untuk membantu proses observasi dan memberikan catatan lapangan selain yang dilakukan oleh peneliti. Penelitian dalam siklus II ini dilakukan sebanyak 4 kali pertemuan atau 8 kali 40 menit.

Bentuk perencanaan pada siklus II ini meliputi :
a. Menyiapkan
Rencana
Pelaksanaan Pembelajaran yang sesuai dengan Standar
Kompetensi dan Kompetensi dasar untuk mata pelajaran TIK

Kelas VIII, dan mengembangkan skenario pembelajaran.

b. Membuat Rencana Pelaksanaan Pembelajaran (RPP) yang akan dilaksanakan pada siklus II ini dengan menggunakan Metode Tutor Sebaya.

c. Melanjutkan kelompok dan tutor yang telah ada sebelumnya untuk melaksanakan rencana pembelajaran.

d. Mempersiapkan format observasi motivasi belajar peserta didik dan catatan lapangan (field note) yang akan diamati oleh peneliti dan/atau observer.

e. Guru melakukan pelatihan khusus terhadap tutor selama 1 jam pelajaran diluar jam sekolah.

f. Guru menyiapkan media dan/atau materi yang akan disampaikan oleh tutor serta catatan/panduan yang diperlukan.

\section{Pelaksanaan Tindakan Siklus II}

Kelompok yang menjadi tutor masuk ruang komputer untuk mendapat materi secara langsung dari guru pengajar selama 1 jam pelajaran ( \pm 40 menit $)$ diluar jam pelajaran sehari sebelumnya.

Selanjutnya masing-masing gelombang siswa akan masuk ruang komputer selama 40 menit sesuai kelompoknya masing-masing dengan dibimbing oleh kelompok tutor. Guru memberikan gambaran umum tentang materi. Tutor 
mengamati cara siswa menghidupkan komputer. Tutor memandu siswa praktik membuat dokumen baru, mengatur lebar kolom dan baris, menyimpan dokumen, menyimpan dokumen pada folder dan mengamati menonaktifkan komputer dengan menggunakan panduan yang telah disiapkan. Guru atau observer melakukan pengamatan dan memberikan catatan lapangan.

Tutor memandu siswa praktik pengaturan halaman pada dokumen, melakukan pencetakan dokumen, dan menyimpan dokumen sesuai dengan worsheet yang dikehendaki dengan menggunakan panduan yang telah disiapkan. Guru atau observer melakukan pengamatan dan memberikan catatan lapangan. Siswa mengerjakan tugas evaluasi KD 2.4 yang diperintahkan pada kelompoknya diawasi tutor dan dipantau oleh guru dan/atau observer.

\section{Pengamatan}

Pada siklus II ini dilaksanakan 2 kali observasi terhadap instrument motivasi belajar, yaitu pada pertengahan siklus dan pada akhir siklus bersamaan dengan evaluasi KD 2.4. Kedua evaluasi ini menunjukkan bahwa diperoleh data peningkatan motivasi belajar yang ternyata diiringi dengan peningkatan ketuntasan belajar siswa.

Hasil pengamatan terhadap instrument motivasi dan hasil evaluasi belajar siswa pada siklus II serta perbandingan dengan siklus I dan observasi awal ditunjukkan pada tabel-tabel berikut:

Tabel 4.12.

Perbandingan Kualitas Motivasi Belajar Sebelum Dan Sesudah Menggunakan Metode Tutor Sebaya

\begin{tabular}{|c|c|c|c|c|c|c|c|c|c|c|c|c|c|c|c|}
\hline \multirow{3}{*}{$\begin{array}{c}\begin{array}{c}\text { Perbandingan } \\
\text { Kualitas Motivasi } \\
\text { Belajar }\end{array} \\
\text { Kualitas Motivasi }\end{array}$} & \multirow{2}{*}{\multicolumn{3}{|c|}{ Observasi Awal }} & \multicolumn{6}{|c|}{ Observasi Pada Siklus 1} & \multicolumn{6}{|c|}{ Observasi Pada Siklus 2} \\
\hline & & & & & Observa & & & Observas & & & Observa & & & Observa & \\
\hline & \multicolumn{2}{|c|}{ Jlh siswa } & & \multicolumn{2}{|c|}{ Jlh siswa } & & \multicolumn{2}{|c|}{ Jlh siswa } & & \multicolumn{2}{|c|}{ Jlh siswa } & & \multicolumn{2}{|c|}{ Jlh siswa } & \\
\hline Baik Sekali & 2 & $4.65 \%$ & \multirow{2}{*}{$13.95 \%$} & 4 & $9.09 \%$ & \multirow{2}{*}{$22.73 \%$} & 6 & $13.64 \%$ & \multirow{2}{*}{$\begin{array}{c}50.00 \\
\%\end{array}$} & 9 & $20.45 \%$ & \multirow{2}{*}{$\begin{array}{c}77.27 \\
\%\end{array}$} & 16 & $36.36 \%$ & \multirow{2}{*}{$88.64 \%$} \\
\hline Baik & 4 & $9.30 \%$ & & 6 & $13.64 \%$ & & 16 & $36.36 \%$ & & 25 & $56.82 \%$ & & 23 & $52.27 \%$ & \\
\hline Sedang & 10 & $23.26 \%$ & \multirow{2}{*}{$-86.05 \%$} & 13 & $29.55 \%$ & \multirow{2}{*}{$77.27 \%$} & 12 & $27.27 \%$ & \multirow{2}{*}{$\begin{array}{c}50.00 \\
\%\end{array}$} & 8 & $18.18 \%$ & \multirow{2}{*}{$\begin{array}{c}22.73 \\
\%\end{array}$} & 5 & $11.36 \%$ & \multirow{2}{*}{$11.36 \%$} \\
\hline Kurang & 27 & $62.79 \%$ & & 21 & $47.73 \%$ & & 10 & $22.73 \%$ & & 2 & $4.55 \%$ & & 0 & $0.00 \%$ & \\
\hline Jumlah & 43 & $100 \%$ & $100 \%$ & 44 & $100 \%$ & $100 \%$ & 44 & $100 \%$ & $100 \%$ & 44 & $100 \%$ & $100 \%$ & 44 & $100 \%$ & $100 \%$ \\
\hline Rerata Capaian & & $42.83 \%$ & & & $44.21 \%$ & & & $68.04 \%$ & & & $73.65 \%$ & & & $76.56 \%$ & \\
\hline
\end{tabular}


Tabel 4.13. Perbandingan Hasil Evaluasi Belajar Sebelum dan Setelah Menggunakan Metode Tutor Sebaya

\begin{tabular}{|c|c|c|c|c|c|c|c|c|}
\hline \multirow{3}{*}{$\begin{array}{c}\text { Perbandingan Hasil } \\
\text { Belajar }\end{array}$} & \multirow{2}{*}{\multicolumn{2}{|c|}{ Observasi Awal }} & \multicolumn{4}{|c|}{ Observasi Pada Siklus 1} & \multirow{2}{*}{\multicolumn{2}{|c|}{$\begin{array}{l}\text { Observasi Pada } \\
\text { Siklus } 2\end{array}$}} \\
\hline & & & \multicolumn{2}{|c|}{ Observasi 1} & \multicolumn{2}{|c|}{ Observasi 2} & & \\
\hline & 80 & & 100 & & 100 & & 48 & \\
\hline Nilai Terendah & 28 & & 37.5 & & 50 & & 30 & \\
\hline Rata-Rata Nilai & 50.79 & & 62.50 & & 68.98 & & 37.82 & \\
\hline Ketuntasan & 6 & $13.95 \%$ & 11 & $25.00 \%$ & 26 & $59.09 \%$ & 40 & $90.91 \%$ \\
\hline Tidak Tuntas & 37 & $86.05 \%$ & 33 & $75.00 \%$ & 18 & $40.91 \%$ & 4 & $9.09 \%$ \\
\hline \multicolumn{9}{|l|}{ KEHADIRAN } \\
\hline Hadir & 43 & $95.56 \%$ & 44 & $97.78 \%$ & 44 & $97.78 \%$ & 44 & $97.78 \%$ \\
\hline Tidak Hadir & 2 & $4.44 \%$ & 1 & $2.22 \%$ & 1 & $2.22 \%$ & 1 & $2.22 \%$ \\
\hline $\begin{array}{l}\text { Jumlah } \\
\text { Keseluruhan }\end{array}$ & 45 & $100.00 \%$ & 45 & $100.00 \%$ & 45 & $100.00 \%$ & 45 & $100.00 \%$ \\
\hline
\end{tabular}

\section{Refleksi}

Berdasarkan dari temuan diatas maka dapat dikatakan bahwa telah terjadi peningkatan motivasi belajar siswa kearah yang makin baik, hal ini terlihat dari terus berkurangnya siswa yang memiliki motivasi belajar rendah (Sedang dan Kurang) antara sebelum dan sesudah menggunakan metode tutor sebaya.

Peningkatan terus terjadi ketika dilaksanakan siklus 2, dimana pada pertengahan siklus 2 siswa yang bermotivasi tinggi (Baik dan Baik Sekali) sudah mencapai 77. $27 \%$, dengan rerata capaian $73.65 \%$ dari indikator motivasi belajar siswa, dan pada akhir siklus 2 bahkan mencapai $88.64 \%$ dengan rerata capaian $76.56 \%$ dari indikator motivasi belajar siswa.

$$
\text { Peningkatan ketuntasan }
$$

belajar juga terjadi ketika dilaksanakan siklus 2, dimana pada akhir siklus 2 ketuntasan belajar siswa bahkan mencapai $90.91 \%$ dengan kehadiran siswa $97.78 \%$.

Pemberian pembinaan secara terpisah menyebabkan waktu kegiatan tutor sebaya selama 1 jam pelajaran ( \pm 40 menit $)$ diluar jam pelajaran telah memperpanjang pelaksanaan tutor sebaya untuk 2 gelombang menjadi full 80 menit (2 x 40 menit). Pemberian bimbingan yang terpisah ini diteruskan pada siklus 2 dan pemberian catatan/panduan yang diperlukan telah menghasilkan peningkatan motivasi belajar siswa pada setiap siklus.

\section{Pembahasan}

Berdasarkan temuan-temuan diatas maka disimpulkan telah terjadi peningkatan motivasi belajar siswa yang makin baik setelah dilakukan perubahan metode belajar menggunakan tutor sebaya. Hal ini ditunjukkan dengan berkurangnya siswa yang 
bermotivasi belajar rendah (Sedang dan Kurang) antara sebelum dan sesudah menggunakan metode tutor sebaya. Pada observasi awal ditemukan siswa yang bermotivasi tinggi (Baik dan Baik Sekali) hanya sebanyak $13.95 \%$ pada awal observasi, selanjutnya mengalami kenaikan menjadi $22.73 \%$ pada pertengahan siklus 1 dan menjadi $50.00 \%$ pada akhir siklus 1 . Peningkatan terus terjadi ketika dilaksanakan siklus 2, dimana pada pertengahan siklus 2 siswa yang bermotivasi tinggi (Baik dan Baik Sekali) sudah mencapai 77. 27\% dengan rerata capaian $73.65 \%$ dari indikator motivasi belajar siswa, dan pada akhir siklus 2 bahkan mencapai $88.64 \%$ dengan rerata capaian $76.56 \%$ dari indikator motivasi belajar siswa.

Peningkatan ketuntasan

belajar juga mengalami kenaikan antara sebelum dan sesudah menggunakan metode tutor sebaya. Pada observasi awal ketuntasan belajar hanya pada 6 orang siswa (13.95\%), setelah menggunakan metode tutor sebaya mengalami kenaikan pada pertengahan siklus 1 yaitu menjadi 11 orang siswa (25.58\%), dan menjadi 26 orang siswa $(60.47 \%)$ pada akhir siklus 1 . Peningkatan terus terjadi ketika dilaksanakan siklus 2, dimana pada akhir siklus 2 ketuntasan belajar siswa bahkan mencapai $90.91 \%$ dengan kehadiran siswa $97.78 \%$.

Peningkatan ini tidak lepas perubahan tindakan yang dilakukan yaitu terhadap tutor dan siswa. Pada awal siklus 1 peneliti membagi waktu ( 2 x 40 menit $=80$ menit $)$, yaitu: 20 menit untuk membina tutor, dan 60 menit $(2 \times 30$ menit) untuk waktu yang disediakan terhadap tutor melakukan pembelajaran pada 2 gelombang. Pada akhir siklus 1, pembinaan terhadap tutor dilakukan secara terpisah, yaitu 30 menit diluar jam pelajaran sekolah dan dalam kegiatannya dikelas para tutor dibekali dengan catatan materi panduan pembelajaran yang akan membantu dalam kegiatan tutor sebaya. Pemberian pembinaan secara terpisah menyebabkan waktu kegiatan tutor sebaya jadi semakin panjang dari 60 menit $(2$ x 30 menit) untuk 2 gelombang menjadi 80 menit ( 2 x 40 menit) untuk 2 gelombang. Pemberian bimbingan yang terpisah ini diteruskan pada siklus 2 dan pemberian catatan/panduan yang diperlukan telah menghasilkan peningkatan motivasi belajar siswa pada setiap siklus.

Temuan ini menguatkan penelitian sebelumnya seperti Burhanudin, dkk. (2012) dalam Journal of Physical Education, Sport, Health and Recreations, yang berjudul Peningkatan Pembelajaran Teknik Dribble Melalui Metode Pembelajaran Tutor Sebaya Pada Siswa Kelas VIII B di MTs Nurul Huda Banyuputih Kabupaten Batang tahun ajaran 2012, bahwa melalui pembelajaran tutor sebaya telah terjadi peningkatan hasil belajar, ini 
dapat dilihat ketuntasan belajar klasikal (kognitif, afektif, dan psikomotor) dari siklus I ke siklus II, serta meningkatnya semangat belajar siswa dalam kondisi dan keadaan apapun.

Hasil penelitian ini juga menguatkan penelitian sebelumnya oleh Maria Ulfa, dkk. (2014) yang berjudul Pengaruh Penerapan Model Pembelajaran Kooperatif Teknik Tutor Sebaya Terhadap Hasil Belajar TIK Ditinjau Dari Motivasi Berprestasi Pada Siswa Kelas VI SD Muhammadiyah 2 Denpasar dalam e-Journal Program Pascasarjana Universitas Pendidikan Ganesha Program Studi Pendidikan Dasar Tahun 2014. Penelitian ini menyimpulkan bahwa terdapat pengaruh interaksi yang signifikan antara model pembelajaran kooperatif teknik tutor sebaya dan motivasi berprestasi siswa terhadap hasil belajar TIK. Berdasarkan temuantemuan di atas dapat disimpulkan metode pembelajaran kooperatif teknik tutor sebaya berpengaruh terhadap hasil belajar TIK siswa.

Berdasarkan data dan uraian diatas maka penelitian tindakan kelas dengan menggunakan metode tutor sebaya pada siklus 2 ini telah melampaui kriteria keberhasilan minimal $60 \%$ dari indikator motivasi belajar yang terdapat pada $75 \%$ siswa, dimana hasil yang dipero leh adalah pemenuhan indikator motivasi belajar siswa telah mencapai $76.56 \%$ dengan ketuntasan belajar pada $90.91 \%$ siswa. Keadaan ini menjadikan penelitian tindakan kelas ini tidak perlu dilanjutkan pada siklus berikutnya.

\section{SIMPULAN DAN SARAN}

Penggunaan metode Peer Tutoring (Tutor Sebaya) terbukti mampu menghilangkan kejenuhan siswa dan meningkatkan motivasi belajar siswa dibandingkan menggunakan metode konvensional.

Penggunaan metode Tutor Sebaya telah mengurangi siswa yang memiliki motivasi belajar rendah (Sedang dan Kurang). Pada observasi awal ditemukan siswa yang bermotivasi tinggi (Baik dan Baik Sekali) hanya sebanyak $13.95 \%$ dengan rerata capaian $42.83 \%$ dari indikator motivasi belajar siswa pada awal observasi. Kenaikan motivasi belajar siswa terus terjadi menjadi $22.73 \%$ dengan rerata capaian $44.21 \%$ dari indikator motivasi belajar siswa pada pertengahan siklus 1 dan menjadi $50.00 \%$ dengan rerata capaian $68.04 \%$ dari indikator motivasi belajar siswa pada akhir siklus 1. Peningkatan motivasi belajar terus terjadi saat pelaksanaan siklus 2, pada pertengahan siklus 2 siswa yang bermotivasi tinggi (Baik dan Baik Sekali) sudah mencapai 77. $27 \%$ dengan rerata capaian $73.65 \%$ dari indikator motivasi belajar siswa, dan pada akhir siklus 2 bahkan mencapai $88.64 \%$ dengan rerata capaian $76.56 \%$ dari indikator motivasi belajar siswa. 
Keberhasilan penggunaan metode Tutor Sebaya ini tidak terlepas dari perubahan tindakan yang dilakukan terhadap tutor dan siswa. Pemberian waktu pembelajaran khusus kepada siswa tutor semakin panjang, dan pemberian catatan materi panduan pembelajaran membuat kemampuan siswa tutor semakin meningkat, pada akhirnya meningkatkan setiap hasil yang hendak dicapai, baik motivasi maupun hasil evaluasi belajar siswa secara keseluruhan.

\section{DAFTAR RUJUKAN}

Ahmadi, Abu \& Supriono, Widodo. 2004. Belajar dan Menifestasinya. Bandung: Rajawali.

Anni, Chatarina Tri. 2007. Psikologi Belajar. Semarang: UPT MKK UNNES.

Burhanudin, M., Sulaiman, dan Annas, M. 2012. Efektivitas Metode Pembelajaran Tutor Sebaya. Journal of Physical Education, Sport, Health and Recreations. (Online), Jurusan Pendidikan Jasmani Kesehatan dan Rekreasi, Fakultas Ilmu Keolahragaan, Universitas Negeri Semarang, Indonesia. http://journal.unnes.ac.id/sju/in dex.php/peshr/article/viewFile/ 444/491 (diunduh pada 6 Maret 2015).

Danusastro. 2003. Strategi Belajar Mengajar Efektif. Jakarta: Media Pratama.
Djamarah, Syaiful Bahri. 2000. Guru Dan Anak Didik Dalam Interaksi Edukatif. Jakarta: PT Rineka Cipta.

Endang, Lusi. 2009. Buku Pelajaran Teknologi Informasi dan Komunikasi Untuk SMP / MTs Kelas VIII. Jakarta: Kementerian Negara Riset dan Teknologi.

Hamalik, Oemar. 1991. Strategi Belajar-Mengajar berdasarkan CBSA. Bandung: CV. Sinar Baru.

Hardana. 2000. Antisipasi Pengembangan Pendidikan Dalam Rangka Otonomi Daerah. Bandung: UPI Press. Makmun, Abin Syamsudin. 2007. Psikologi Kependidikan; Perangkat Sistem Pengajaran Modul. Cetakan ke 10. Bandung: PT Remaja Rosdakarya.

Nawawi. 2001. Dasar - Dasar Perencanaan Pengajaran. Jakarta: Raja Grafindo Persada. Peraturan Pemerintah Nomor 19 Tahun 2005 tentang Standar Nasional Pendidikan.

Permana, Budi. 2001. Seri Penuntun Praktis Microsoft Exel 2002. Jakarta: PT Gramedia.

Purwoto. 2000. Strategi Belajar Mengajar Matematika.

Surakarta: Bandung: UNS Press.

Rustam dan Mudilarto. 2004. Penelitian Tindakan Kelas. Jakarta: Direktorat Pembinaan Pendidikan Tenaga Kependidikan dan Ketenagaan 
Perguruan Tinggi Direktorat

Jenderal Pendidikan Tinggi

Departemen Pendidikan

Nasional.

Sagala, H. Syaiful. 2006. Konsep

Dan Makna Pembelajaran.

Bandung: CV Alfabeta.

Sardiman, AM. 2011. Interaksi dan

Motivasi Belajar Mengajar.

Jakarta: PT Raja Grafindo

Persada.

Silberman, L. Melvin. 2001. Strategi

Pembelajaran Aktif.

Terjemahan oleh Sarjuli, Ammar Adzfar, Sutrisno, dkk. 2009. Yogyakarta: Pustaka Insan Madani.

Sobour, Alex. 2003. Psikologi Umum dalam Lintasan Sejarah. Bandung: CV Pustaka Setia.

Sudjana, Nana. 2003. Perencanaan Pengajaran. Jakarta: P2LPTK.

Undang-Undang Republik Indonesia Nomor 20 Tahun 2003. Sistem Pendidikan Nasional.

Kementerian Pendidikan Nasional.

Uno, Hamzah B. 2009. Teori Motivasi dan Pengukurannya. Jakarta: Bumi Aksara.

Zaini, Hisyam., Munthe, Bermawy,. dan Aryani, Sekar Ayu. 2000. Strategi Pembelajaran Aktif. Yogyakarta: CTSD Institut Agama Islam Negeri Sunan Kalijaga. 